\title{
In vitro binding and receptor-mediated activity of terlipressin at vasopressin receptors $V_{1}$ and $V_{2}$
}

This article was published in the following Dove Press journal:

Journal of Experimental Pharmacology

\author{
Khurram Jamil' \\ Stephen Chris Pappas ${ }^{2}$ \\ Krishna R Devarakonda' \\ 'Clinical Development, Mallinckrodt \\ Pharmaceuticals, Bedminster, ${ }^{2}$ Orphan \\ Therapeutics, LLC, Lebanon, NJ, USA
}

Correspondence: Khurram Jamil Clinical Development, Mallinckrodt Pharmaceuticals, 1405 U.S. Route 206, Bedminster, NJ 07921, USA

$\mathrm{Tel}+\mathrm{I} 9085004716$

Fax + I 8665729449

Email Khurram.Jamil@mallinckrodt.com

\begin{abstract}
Terlipressin, a synthetic, systemic vasoconstrictor with selective activity at vasopressin-1 $\left(\mathrm{V}_{1}\right)$ receptors, is a pro-drug for the endogenous/natural porcine hormone [Lys ${ }_{8}$ ]vasopressin (LVP). We investigated binding and receptor-mediated cellular activities of terlipres$\sin , \mathrm{LVP}$, and endogenous human hormone [ $\mathrm{Arg}_{8}$ ]-vasopressin (AVP) at $\mathrm{V}_{1}$ and vasopressin-2 $\left(\mathrm{V}_{2}\right)$ receptors. Cell membrane homogenates of Chinese hamster ovary cells expressing human $\mathrm{V}_{1}$ and $\mathrm{V}_{2}$ receptors were used in competitive binding assays to measure receptor-binding activity. These cells were used in functional assays to measure receptor-mediated cellular activity of terlipressin, LVP, and AVP. Binding was measured by $\left[{ }^{3} \mathrm{H}\right]$ AVP counts, and the activity was measured by fluorometric detection of intracellular calcium mobilization $\left(\mathrm{V}_{1}\right)$ and cyclic adenosine monophosphate $\left(\mathrm{V}_{2}\right)$. Binding potency at $\mathrm{V}_{1}$ and $\mathrm{V}_{2}$ was $\mathrm{AVP}>\mathrm{LVP}>>$ terlipressin. LVP and terlipressin had approximately sixfold higher affinity for $\mathrm{V}_{1}$ than for $\mathrm{V}_{2}$. Cellular activity potency was also $A V P>L V P>>$ terlipressin. Terlipressin was a partial agonist at $\mathrm{V}_{1}$ and a full agonist at $\mathrm{V}_{2}$; LVP was a full agonist at both $\mathrm{V}_{1}$ and $\mathrm{V}_{2}$. The in vivo response to terlipressin is likely due to the partial $\mathrm{V}_{1}$ agonist activity of terlipressin and full $\mathrm{V}_{1}$ agonist activity of its metabolite, LVP. These results provide supportive evidence for previous findings and further establish terlipressin pharmacology for vasopressin receptors.
\end{abstract}

Keywords: hormones, in vitro techniques, pharmacology, hepatorenal syndrome

\section{Introduction}

Terlipressin ( $N^{\alpha}$-tryglycl-8-lysine-vasopressin), a pro-drug for the endogenous/natural porcine hormone $\left[\mathrm{Lys}_{8}\right]$-vasopressin (LVP), ${ }^{1,2}$ is a synthetic vasopressin analog derived from the natural/endogenous human hormone $\left[\mathrm{Arg}_{8}\right]$-vasopressin (AVP). Terlipressin differs from AVP in the substitution of lysine for arginine at the eighth position of endogenous AVP and the addition of three glycyl residues at the amino terminus (Figure 1). Large randomized clinical studies in patients with hepatorenal syndrome type 1 have shown that intravenous administration of terlipressin improves renal function in this setting. ${ }^{3,4}$ Terlipressin exerts its effects via its partial vasopressin- $1\left(\mathrm{~V}_{1}\right)$ agonist activity and the full $\mathrm{V}_{1}$ agonist activity of its metabolite, LVP. ${ }^{5}$ Findings from experimental studies conducted in rat and human tissues provide convincing evidence of the rapid, acute vasopressor function of terlipressin following intravenous bolus administration of clinically relevant doses, as well as the longer term vasoconstrictive effects achieved through terlipressin conversion to LVP. ${ }^{6}$

$\mathrm{V}_{1}$ receptors (previously known as $\mathrm{V}_{1 \mathrm{a}}$ receptors) are located on vascular smooth muscle in the kidney, myometrium, bladder, liver, spleen, platelets, and fat tissue; $\mathrm{V}_{1}$ receptors mediate vasoconstriction, hepatic glycogenolysis, and platelet aggregation. ${ }^{7,8}$ 
Vasopressin-2 $\left(\mathrm{V}_{2}\right)$ receptors are located on the basolateral membrane of the distal tubule and collecting ducts in the kidney; $\mathrm{V}_{2}$ receptors mediate the antidiuretic effects of vasopressin. ${ }^{7}$ Cleavage of the $N$-triglycyl residue on terlipressin occurs in vivo, resulting in a prolonged duration of action for terlipressin compared with LVP. ${ }^{7}$ The purpose of this study was to investigate the binding activities and receptormediated cellular activities of terlipressin, LVP, and AVP at vasopressin receptor subtypes $\mathrm{V}_{1}$ and $\mathrm{V}_{2}$ in vitro. Notably, vasopressin-3 receptors (previously known as $\mathrm{V}_{1 \mathrm{~b}}$ receptors) were not investigated in this study because they are not relevant to the hepatorenal syndrome type 1 disease state.

\section{Materials and methods}

\section{Cell lines}

Chinese hamster ovary $(\mathrm{CHO})$ cells expressing human $\mathrm{V}_{1}$ receptors (line CHO-S; study numbers 20404, 21104, and 100009187; Cerep, Celle l'Evescault, France) and human $\mathrm{V}_{2}$ receptors (line CHO-K1; study numbers 20404, 21104, and 100009187; Cerep) ${ }^{9}$ were used for the competitive binding and functional assays (Table 1). ${ }^{9,10}$ The expression of vasopressin receptors was approximately fivefold higher in the $\mathrm{V}_{2}$ cell line; thus, different amounts of cell membrane proteins or cells were used in the assays (Table 2).

\section{Competitive binding assays}

Cell membrane homogenates were prepared from cells of the CHO-S and CHO-K1 cell lines (study numbers 20404,
21104, and 100009187; Cerep). [ $\left.{ }^{3} \mathrm{H}\right] \mathrm{AVP}$ at a concentration of $0.3 \mathrm{nM}$ was added to each cell membrane homogenate $\left(\mathrm{V}_{1}\right.$ assay: $40-\mu \mathrm{g}$ protein; $\mathrm{V}_{2}$ assay: $16-\mu \mathrm{g}$ protein), which was then incubated $\left(\mathrm{V}_{1}\right.$ assay: 60 minutes; $\mathrm{V}_{2}$ assay: 120 minutes) at $22^{\circ} \mathrm{C}$ with various concentrations of terlipressin, LVP, and AVP in assay buffer containing Tris- $\mathrm{HCl} 50 \mathrm{mM}$ ( $\mathrm{pH} 7.4$ ), $\mathrm{MgCl}_{2} 5 \mathrm{mM}$, and $0.1 \%$ bovine serum albumin (Table 2). The following terlipressin concentrations were tested (molar): $1.0 \times 10^{-3}, 3.0 \times 10^{-4}, 1.0 \times 10^{-4}, 3.0 \times 10^{-5}$, $1.0 \times 10^{-5}, 3.0 \times 10^{-6}, 1.0 \times 10^{-6}, 3.0 \times 10^{-7}, 1.0 \times 10^{-7}$, and $1.0 \times 10^{-8} \mathrm{M}$. The following LVP and AVP concentrations were tested (molar): $1.0 \times 10^{-6}, 1.0 \times 10^{-7}, 3.0 \times 10^{-8}$, $1.0 \times 10^{-8}, 3.0 \times 10^{-9}, 1.0 \times 10^{-9}, 3.0 \times 10^{-10}, 1.0 \times 10^{-10}$, $3.0 \times 10^{-11}, 1.0 \times 10^{-11}$, and $1.0 \times 10^{-12} \mathrm{M}$. Nonspecific binding was determined in the presence of AVP $1 \mu \mathrm{M}$. All assays were performed in triplicate.

After incubation, samples were filtered rapidly under vacuum through glass fiber filters (GF/B; Packard Bioscience Company, Meriden, CT, USA [now PerkinElmer, Inc., Waltham, MA, USA]) presoaked with $0.3 \%$ polyethylenimine and rinsed several times with ice-cold Tris-HCl $50 \mathrm{mM}$ buffer in a 96-sample cell harvester (UniFilter; PerkinElmer, Inc.). The filters were air dried, and the radioactivity retained in the filters was counted in a scintillation counter (TopCount; PerkinElmer, Inc.) in a scintillation cocktail (MicroScint 0; PerkinElmer, Inc.). The standard reference agonist for $\mathrm{V}_{1}$ was $\left[\mathrm{d}\left(\mathrm{CH}_{2}\right)_{5}{ }^{1}, \mathrm{Tyr}(\mathrm{Me})_{2}\right]$-AVP, and the standard reference agonist for $\mathrm{V}_{2}$ was AVP. These reference compounds were tested at

\section{Terlipressin \\ Lysine-vasopressin (LVP) \\ Cys-Tyr-Phe-GIn-Asn-Cys-Pro-Lys-Gly- $\mathrm{NH}_{2}$ \\ Arginine-vasopressin (AVP) \\ Cys-Tyr-Phe-GIn-Asn-Cys-Pro-Arg-Gly- $\mathrm{NH}_{2}$}

H-Gly-Gly-Gly-Cys-Tyr-Phe-GIn-Asn-Cys-Pro-Lys-Gly- $\mathrm{NH}_{2}$

Figure I Molecular formulas for terlipressin, lysine-vasopressin, and arginine-vasopressin.

Abbreviations: AVP, $\left[\mathrm{Arg}_{8}\right]$-vasopressin; LVP, [ $\left.\mathrm{Lys}_{8}\right]$-vasopressin.

Table I Cells and reference compounds

\begin{tabular}{|c|c|c|c|}
\hline Assays & Cells & $\begin{array}{l}\text { Receptor density } \\
\text { (B }{ }_{\max } \text {, fmol/mg protein) }\end{array}$ & Reference compound \\
\hline \multicolumn{4}{|l|}{ Binding } \\
\hline Human $\mathrm{V}_{1}$ (agonist radioligand) ${ }^{9}$ & Human recombinant (CHO-S cells) & 880 & {$\left[\mathrm{~d}\left(\mathrm{CH}_{2}\right)_{5}{ }_{5}, \mathrm{Tyr}(\mathrm{Me})_{2}\right]-\mathrm{AVP}$} \\
\hline Human $\mathrm{V}_{2}$ (agonist radioligand) ${ }^{9}$ & Human recombinant ( $\mathrm{CHO}-\mathrm{KI}$ cells) & 4000 & AVP \\
\hline \multicolumn{4}{|l|}{ Functional } \\
\hline Human $V_{1}$ (agonist effect) ${ }^{9}$ & Human recombinant (CHO-S cells) & 880 & AVP \\
\hline Human $V_{2}$ (agonist effect) ${ }^{10}$ & Human recombinant ( $\mathrm{CHO}-\mathrm{KI}$ cells) & 4000 & AVP \\
\hline
\end{tabular}

Abbreviations: AVP, $\left[\mathrm{Arg}_{8}\right]$-vasopressin; $\mathrm{B}_{\max }$, maximum number of receptor-binding sites; $\mathrm{CHO}$, Chinese hamster ovary; fmol, fentomole; $\mathrm{V}_{1}$, vasopressin-I; $\mathrm{V}_{2}$, vasopressin-2. 
Table 2 Experimental conditions

\begin{tabular}{|c|c|c|c|c|c|c|}
\hline Binding assays & $\begin{array}{l}\text { Cell membrane } \\
\text { homogenates }\end{array}$ & Ligand & Concentration & Nonspecific & Incubation & $\begin{array}{l}\text { Method of } \\
\text { detection }\end{array}$ \\
\hline $\begin{array}{l}\text { Human } \mathrm{V}_{1} \text { (agonist } \\
\text { radioligand) }\end{array}$ & $40 \mu g$ protein & {$\left[{ }^{3} \mathrm{H}\right] \mathrm{AVP}$} & $0.3 \mathrm{nM}$ & $\operatorname{AVP}(I \mu M)$ & $\begin{array}{l}60 \text { minutes at room } \\
\text { temperature }\end{array}$ & $\begin{array}{l}\text { Scintillation } \\
\text { counting }\end{array}$ \\
\hline $\begin{array}{l}\text { Human } \mathrm{V}_{2} \text { (agonist } \\
\text { radioligand) }\end{array}$ & $16 \mu g$ protein & {$\left[{ }^{3} \mathrm{H}\right] \mathrm{AVP}$} & $0.3 \mathrm{nM}$ & $\operatorname{AVP}(I \mu M)$ & $\begin{array}{l}120 \text { minutes at room } \\
\text { temperature }\end{array}$ & $\begin{array}{l}\text { Scintillation } \\
\text { counting }\end{array}$ \\
\hline Functional assays & Cell density/well & Stimulus & & $\begin{array}{l}\text { Measured } \\
\text { component }\end{array}$ & Incubation & $\begin{array}{l}\text { Method of } \\
\text { detection }\end{array}$ \\
\hline $\begin{array}{l}\text { Human } V_{\text {, agonist }} \\
\text { effect) }\end{array}$ & 45,000 & \multicolumn{2}{|c|}{ None (I $\mu$ M AVP for control) } & $\begin{array}{l}\text { Intracellular } \\
\text { (calcium) }\end{array}$ & $\begin{array}{l}60 \text { minutes at room } \\
\text { temperature }\end{array}$ & Fluorometry \\
\hline $\begin{array}{l}\text { Human } V_{2} \text { (agonist } \\
\text { effect) }\end{array}$ & 3000 & \multicolumn{2}{|c|}{ None (I nM AVP for control) } & cAMP & $\begin{array}{l}30 \text { minutes at room } \\
\text { temperature }\end{array}$ & HTRF \\
\hline
\end{tabular}

Abbreviations: AVP, $\left[\mathrm{Arg}_{8}\right]$-vasopressin; $\mathrm{AMP}$, cyclic adenosine monophosphate; HTRF, homogeneous time-resolved fluorescence; $\mathrm{V}_{1}$, vasopressin-I; $\mathrm{V}_{2}$, vasopressin-2.

several concentrations to obtain competition curves from which the concentration achieving half-maximal inhibition concentration $\left(\mathrm{IC}_{50}\right)$ was calculated.

\section{Receptor-mediated cellular activity assays}

Cell cultures were established from the same $\mathrm{CHO}$ cell lines used in the binding assays described earlier (Table 1). ${ }^{9},{ }^{10} \mathrm{Cells}$ expressing human $\mathrm{V}_{1}$ receptors were suspended in Dulbecco's Modified Eagle Medium (Thermo Fisher Scientific, Waltham, MA, USA), complemented with $0.1 \%$ fetal calf serum, and then distributed in microplates at a density of 45,000 cells per well (Table 2). The fluorescent probe (Fluo4 NW; Thermo Fisher Scientific) was mixed with probenecid in Hank's balanced salt solution buffer (Thermo Fisher Scientific) complemented with N-2-hydroxyethylpiperazine-N-2-ethane sulfonic acid (HEPES) $20 \mathrm{mM}$ buffer (pH 7.4; Thermo Fisher Scientific) and added into each well and equilibrated with the cells for 60 minutes at $37^{\circ} \mathrm{C}$, and then for 15 minutes at $22^{\circ} \mathrm{C}$. Assay plates were then positioned in a microplate reader (CellLux; PerkinElmer, Inc.) for the addition of various concentrations of terlipressin, LVP, and AVP and for subsequent measurements of activity. The following terlipressin concentrations were tested (molar): $1.0 \times 10^{-3}, 1.0 \times 10^{-4}$, $1.0 \times 10^{-5}, 3.0 \times 10^{-6}, 1.0 \times 10^{-6}, 3.0 \times 10^{-7}, 1.0 \times 10^{-7}$, $3.0 \times 10^{-8}, 1.0 \times 10^{-8}, 3.0 \times 10^{-9}, 1.0 \times 10^{-9}, 1.0 \times 10^{-10}$, and $1.0 \times 10^{-11} \mathrm{M}$. The following LVP and AVP concentrations were tested (molar): $1.0 \times 10^{-4}, 1.0 \times 10^{-5}, 1.0 \times 10^{-6}$, $1.0 \times 10^{-7}, 1.0 \times 10^{-8}, 3.0 \times 10^{-9}, 1.0 \times 10^{-9}, 3.0 \times 10^{-10}$, $1.0 \times 10^{-10}, 3.0 \times 10^{-11}, 1.0 \times 10^{-11}, 3.0 \times 10^{-12}, 1.0 \times 10^{-12}$, $1.0 \times 10^{-13}$, and $1.0 \times 10^{-14} \mathrm{M}$. All assays were performed in triplicate. Changes in fluorescence intensity reflected changes in the concentration of free cytosolic calcium. The standard reference agonist was AVP.

The activity at $V_{2}$ receptors was measured based on cyclic adenosine monophosphate (cAMP) production using the homogeneous time-resolved fluorescence method. Cells expressing human $\mathrm{V}_{2}$ receptors were suspended in Hank's balanced salt solution buffer complemented with HEPES $20 \mathrm{mM}$ buffer ( $\mathrm{pH} 7.4$ ), $0.01 \%$ bovine serum albumin, and isobutylmethylxanthine $0.5 \mathrm{mM}$, and then distributed in microplates at a density of 3000 cells per well and preincubated for 5 minutes at room temperature in the absence (control) or in the presence of the various concentrations of terlipressin, LVP, AVP, and the reference antagonist ([adamantaneacetyl ${ }^{1}$, $O$-Et-D-Tyr ${ }^{2}, \mathrm{Val}^{4}$, aminobutyryl $\left.{ }^{6}\right]$-AVP). Next, the reference agonist, AVP, was added to a final concentration of $0.03 \mathrm{nM}$. After 30 minutes of incubation at room temperature, the cells were lysed, and the fluorescence acceptor (D2-labeled cAMP) and the fluorescence donor (anti-cAMP antibody labeled with europium cryptate) were added. After 60 minutes of incubation at room temperature, the plates were positioned in a microplate reader (RUBYstar; BMG Labtech, Cary, $\mathrm{NC}$, USA), and fluorescence transfer was measured at $\lambda \mathrm{ex}=$ $337 \mathrm{nM}$ and $\lambda \mathrm{em}=620$ and $665 \mathrm{nM}$. The following terlipressin concentrations were tested (molar): $1.0 \times 10^{-3}, 1.0 \times 10^{-4}$, $1.0 \times 10^{-5}, 3.0 \times 10^{-6}, 1.0 \times 10^{-6}, 3.0 \times 10^{-7}, 1.0 \times 10^{-7}$, $3.0 \times 10^{-8}, 1.0 \times 10^{-8}, 3.0 \times 10^{-9}, 1.0 \times 10^{-9}, 1.0 \times 10^{-10}$, and $1.0 \times 10^{-11} \mathrm{M}$. The LVP and AVP concentrations were tested (molar): $1.0 \times 10^{-4}, 1.0 \times 10^{-5}, 1.0 \times 10^{-6}, 1.0 \times 10^{-7}$, $1.0 \times 10^{-8}, 3.0 \times 10^{-9}, 1.0 \times 10^{-9}, 3.0 \times 10^{-10}, 1.0 \times 10^{-10}$, $3.0 \times 10^{-11}, 1.0 \times 10^{-11}, 3.0 \times 10^{-12}, 1.0 \times 10^{-12}, 1.0 \times 10^{-13}$, and $1.0 \times 10^{-14} \mathrm{M}$. All assays were performed in triplicate.

The reference compounds for $\mathrm{V}_{1}$ and $\mathrm{V}_{2}$ were tested at several concentrations to obtain concentration-response curves from which the concentration producing half-maximal effective concentration $\left(\mathrm{EC}_{50}\right)$ or $\mathrm{IC}_{50}$ was calculated.

\section{Data analysis}

For the binding assays, specific ligand binding to receptors was defined as the difference between the total binding and 
the nonspecific binding determined in the presence of an excess of unlabeled ligand. Results were expressed as a percentage of control-specific binding (measured specific binding/control-specific binding $\times 100)$ and as percent inhibition of control radioligand-specific binding $(100-[$ measured specific binding/control-specific binding] $\times 100$ ) obtained in the presence of terlipressin, LVP, or AVP. Selectivity of terlipressin and LVP for $\mathrm{V}_{1}$ and $\mathrm{V}_{2}$ receptors was calculated as compared with AVP.

Values for the $\mathrm{IC}_{50}$ and the Hill coefficient $(\mathrm{nH})$ were determined by nonlinear regression analysis of the competition curves generated with mean replicate values using Hill equation curve fitting $\left(\mathrm{Y}=\mathrm{D}+[\mathrm{A}-\mathrm{D}] /\left[1+\left(\mathrm{C} / \mathrm{C}_{50}\right)^{\mathrm{nH}}\right]\right.$, where $\mathrm{Y}=$ specific binding, $\mathrm{D}=$ minimum specific binding, $\mathrm{A}=$ maximum specific binding, $\mathrm{C}=$ test article concentration, $\mathrm{C}_{50}=\mathrm{IC}_{50}$, and $\mathrm{nH}=$ slope factor). Inhibition constants $\left(\mathrm{K}_{\mathrm{i}}\right)$ were calculated from the Cheng Prusoff equation $\left(\mathrm{K}_{\mathrm{i}}=\right.$ $\mathrm{IC}_{50} / 1+[\mathrm{L} / \mathrm{KD}]$, where $\mathrm{L}=$ concentration of radioligand in the assay and $\mathrm{KD}=$ affinity of the radioligand for the receptor).

For the functional assays, results were expressed as a percentage of control agonist response (measured response/control response $\times 100$ ) in the presence of the test article. The $\mathrm{EC}_{50}$ values were determined by nonlinear regression analysis of the functional assay curves generated with mean replicate values using the Hill equation curve fitting $\left(\mathrm{Y}=\mathrm{D}+[\mathrm{A}-\mathrm{D}] /\left[1+\left(\mathrm{C} / \mathrm{C}_{50}\right)^{\mathrm{nH}}\right]\right.$, where $\mathrm{Y}=$ response, $\mathrm{D}=$ right asymptote of the curve, $\mathrm{A}=$ left asymptote of the curve, $\mathrm{C}=$ test article concentration, $\mathrm{C}_{50}=\mathrm{EC}_{50}$, and $\mathrm{nH}=$ slope factor). The results for $\mathrm{V}_{1}$ were expressed as a percentage of the control response to AVP $1 \mu \mathrm{M}$, and the results for $\mathrm{V}_{2}$ were expressed as percent inhibition of the control response to AVP $0.03 \mathrm{nM}$.

\section{Results}

\section{Binding affinity}

Results of the binding affinity assays are summarized in Table 3 and illustrated in Figure 2. The potency of binding affinity of the tested compounds to both $\mathrm{V}_{1}$ and $\mathrm{V}_{2}$ receptors was $A V P>L V P>>$ terlipressin. For $V_{1}$ receptors, the binding affinity of LVP was about twofold less than that of AVP, and the binding affinity of terlipressin was about 600-fold less than that of LVP. For $\mathrm{V}_{2}$ receptors, the binding affinity of LVP

Table 3 Binding affinity assay results

\begin{tabular}{|c|c|c|c|c|c|}
\hline \multirow{2}{*}{$\begin{array}{l}\text { Compound } \\
\text { tested }\end{array}$} & \multicolumn{2}{|c|}{$I C_{50}$ (moles) } & \multicolumn{2}{|l|}{$K_{i}$ (moles) } & \multirow{2}{*}{$\begin{array}{l}\text { Selectivity for } V_{1} \\
\left(K_{i}-V_{2} / K_{i}-V_{1}\right)\end{array}$} \\
\hline & Human $V_{1}$ & Human $V_{2}$ & Human $V_{1}$ & Human $\mathrm{V}_{2}$ & \\
\hline Terlipressin & $1.7 \times 10^{-6}$ & $9.6 \times 10^{-6}$ & $1.1 \times 10^{-6}$ & $6.9 \times 10^{-6}$ & 6.3 \\
\hline LVP & $2.9 \times 10^{-9}$ & $1.4 \times 10^{-8}$ & $1.8 \times 10^{-9}$ & $1.0 \times 10^{-8}$ & 5.6 \\
\hline AVP & $1.3 \times 10^{-9}$ & $1.2 \times 10^{-9}$ & $8.0 \times 10^{-10}$ & $8.5 \times 10^{-10}$ & I.I \\
\hline
\end{tabular}

Abbreviations: AVP, $\left[\mathrm{Arg}_{8}\right]$-vasopressin; $I_{50}$, half-maximal inhibition concentration; $\mathrm{K}_{i}$, inhibition constant; LVP, $\left[\right.$ Lys $\left.{ }_{8}\right]$-vasopressin; $\mathrm{V}_{1}$, vasopressin- I; $\mathrm{V}_{2}$, vasopressin-2.

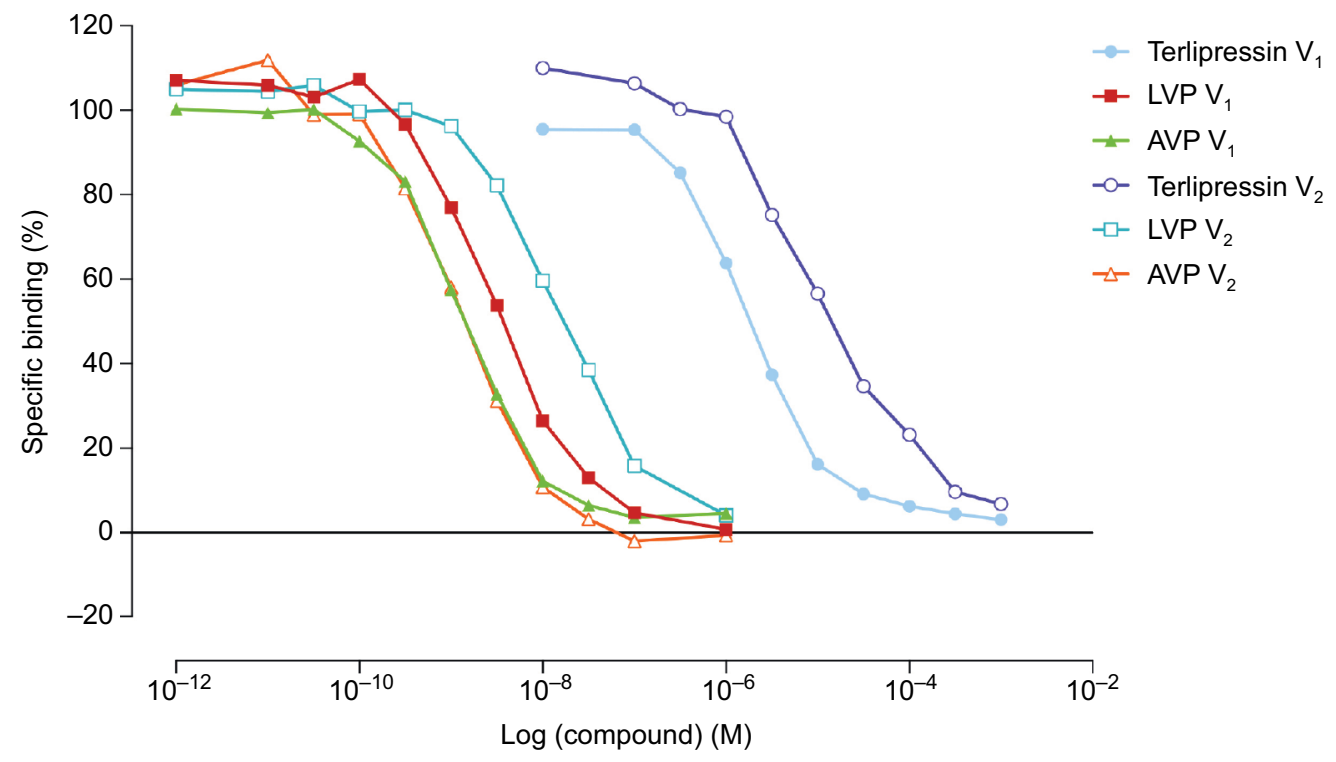

Figure 2 Binding affinity as a function of concentration for the tested compounds.

Abbreviations: AVP, $\left[\mathrm{Arg}_{8}\right]$-vasopressin; LVP, [Lys $]$-vasopressin; $\mathrm{V}_{1}$, vasopressin- I; $\mathrm{V}_{2}$, vasopressin-2. 
was about 12-fold less than that of AVP, and the binding affinity of terlipressin was about 700-fold less than that of LVP.

AVP bound $V_{1}$ and $V_{2}$ receptors with similar high affinities $\left(8.0 \times 10^{-10}\right.$ and $8.5 \times 10^{-10}$, respectively). LVP also bound $\mathrm{V}_{1}$ and $\mathrm{V}_{2}$ receptors with high affinity, but affinity for $\mathrm{V}_{1}$ was about sixfold higher than that for $\mathrm{V}_{2}\left(1.8 \times 10^{-9}\right.$ and $1.0 \times 10^{-8}$, respectively). Terlipressin bound $\mathrm{V}_{1}$ and $\mathrm{V}_{2}$ receptors with low affinity, but affinity for $\mathrm{V}_{1}$ was about sixfold higher than that for $\mathrm{V}_{2}\left(1.1 \times 10^{-6}\right.$ and $6.9 \times 10^{-6}$, respectively $)$.

\section{Cellular activity}

Results of the vasopressin-mediated functional activity assays are summarized in Table 4 and illustrated in Figure 3. The order of potency for cell activation was the same as for the binding assay: AVP $>$ LVP $>>$ terlipressin. LVP was a full agonist at both $\mathrm{V}_{1}$ and $\mathrm{V}_{2}$ receptors, producing maximal cell activation about equal to that of AVP. Terlipressin produced maximal cell activation about equal to that of AVP at $V_{2}$ receptors, and thus was a full agonist at $\mathrm{V}_{2}$ receptors, but it produced only $41 \%$ of the maximal effect observed with
AVP at $\mathrm{V}_{1}$ receptors, indicating that it is a partial agonist at $\mathrm{V}_{1}$ receptors.

\section{Discussion}

Terlipressin is a pro-drug for the endogenous/natural porcine hormone LVP. ${ }^{1,2}$ In the current study, the results of radioligand competitive binding assays in cell membrane homogenates of CHO cells expressing human $\mathrm{V}_{1}$ and $\mathrm{V}_{2}$ receptors demonstrated that terlipressin binds to $\mathrm{V}_{1}$ and $\mathrm{V}_{2}$ receptors with much lower affinities than LVP or AVP. Terlipressin was selective for $V_{1}$ receptors at $a V_{1}: V_{2}$ ratio of $6: 1$. Results of the functional assays indicated that terlipressin behaves as a partial agonist at $\mathrm{V}_{1}$ receptors and a full agonist at $\mathrm{V}_{2}$ receptors.

Our results support findings from previously reported studies and provide additional evidence regarding the pharmacologic properties of terlipressin. ${ }^{2,11,12}$ Colson et al, ${ }^{11}$ using vascular smooth muscle cells isolated from rat aorta and human uterine artery, found that the relative binding affinity $\left(\mathrm{K}_{\mathrm{i}}[\mathrm{nM}]\right)$ of LVP, AVP, and terlipressin for human and rat $V_{1}$ receptors was $A V P>L V P>>$ terlipressin. The mean binding

Table 4 Functional activity assay results

\begin{tabular}{|c|c|c|c|c|}
\hline \multirow[t]{2}{*}{ Compound tested } & \multicolumn{2}{|c|}{$E_{50}$ (moles) } & \multicolumn{2}{|c|}{$\begin{array}{l}\text { Intrinsic activity (maximal activity of test } \\
\text { compound/maximal activity of AVP) }\end{array}$} \\
\hline & Human $V_{1}$ & Human $V_{2}$ & Human V, (\%) & Human $V_{2}(\%)$ \\
\hline Terlipressin & $5.0 \times 10^{-8}$ & $2.8 \times 10^{-8}$ & 41 & $\approx 100$ \\
\hline LVP & $2.9 \times 10^{-10}$ & $2.4 \times 10^{-11}$ & $\approx 100$ & $\approx 100$ \\
\hline AVP & $1.8 \times 10^{-10}$ & $4.4 \times 10^{-12}$ & 100 & 100 \\
\hline
\end{tabular}

Abbreviations: AVP, $\left[\mathrm{Arg}_{8}\right]$-vasopressin; $\mathrm{EC}_{50}$, half-maximal effective concentration; $\mathrm{K}_{\mathrm{i}}$, inhibition constant; LVP, [Lys $]$-vasopressin; $\mathrm{V}_{1}$, vasopressin- I; $\mathrm{V}_{2}$, vasopressin-2.

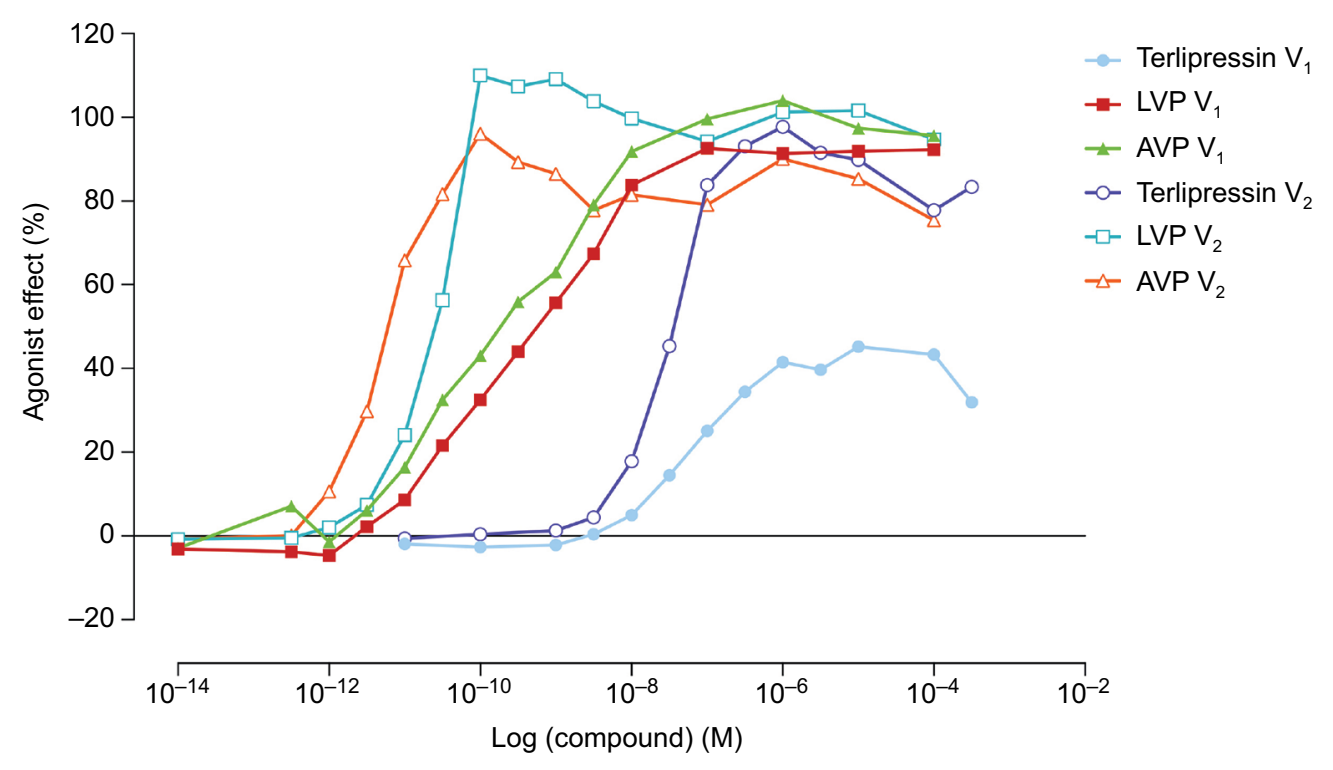

Figure 3 Vasopressin-mediated cell activation as a function of concentration for the tested compounds. Abbreviations: AVP, $\left[\mathrm{Arg}_{8}\right]$-vasopressin; LVP, $\left[\mathrm{Lys}_{8}\right]$-vasopressin; $\mathrm{V}_{1}$, vasopressin- $\mathrm{I} ; \mathrm{V}_{2}$, vasopressin- 2 . 
affinity of terlipressin for human $\mathrm{V}_{1}$ receptors $(1229 \mathrm{nM})$ was about 120 -fold less than the binding affinity of LVP (10 nM); about a 700-fold difference in terlipressin (852 nM) versus LVP binding $(1.2 \mathrm{nM})$ was observed at rat $\mathrm{V}_{1}$ receptors. ${ }^{11}$ Mean maximal cell activation with terlipressin, as measured by intracellular calcium mobilization, was $48 \%$ at human $\mathrm{V}_{1}$ receptors and $66 \%$ at rat $V_{1}$ receptors versus $100 \%$ with LVP. ${ }^{11}$ The selectivity of terlipressin for $\mathrm{V}_{1}$ receptors was 1.9 -fold higher than that for $\mathrm{V}_{2}$ receptors compared with the 6.3-fold higher selectivity observed in our study. This difference may be a reflection of the different cell lines utilized for competitive binding assays (rat and human vascular smooth muscle cells versus $\mathrm{CHO}$ cells, respectively) in the two studies. Bernadich et $\mathrm{al}^{12}$ found that the mean potency of terlipressin for $\mathrm{V}_{1}$ activation in vasopressor tests in a rat model of portal

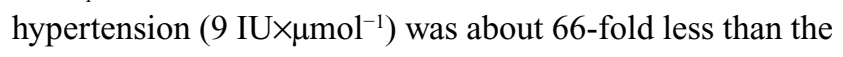

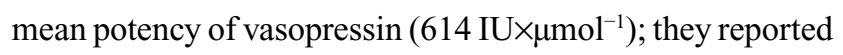
that terlipressin was selective for $\mathrm{V}_{1}$ receptors, with a $\mathrm{V}_{1}: \mathrm{V}_{2}$ ratio of 2.2:1.0 compared with 1:1 for vasopressin. Wisniewski et $\mathrm{al}^{2}$ investigated the potency of terlipressin in vitro for $\mathrm{V}_{1}$ activation in a recombinant system with a functional assay and found that the $\mathrm{EC}_{50}(148 \mathrm{nM})$ was about 150 -fold higher than that for LVP $(0.93 \mathrm{nM})$. In an in vivo model in rats, the investigators showed that LVP and AVP were similar in time to effect and magnitude of effect in raising arterial blood pressure when given at identical doses; in contrast, a 100-fold higher dose of terlipressin was required to achieve a similar effect with a slower onset of action. ${ }^{2}$

Because terlipressin is metabolized to LVP, which is a potent, full $\mathrm{V}_{1}$ receptor agonist in vivo, our data support the theory that the principal pharmacologic response to terlipressin administration is most likely attributable to the LVP metabolite. $^{1}$

\section{Conclusion}

These data suggest that the in vivo pharmacologic response to the administration of terlipressin primarily reflects LVPmediated activation of $\mathrm{V}_{1}$ receptors. However, terlipressin demonstrated agonist activity at both $\mathrm{V}_{1}$ and $\mathrm{V}_{2}$ receptors. Results from the current study provide additional, supportive evidence for previous findings and further establish the binding affinity, potency, and selectivity of terlipressin at vasopressin receptors.

\section{Acknowledgments}

This study was sponsored by Mallinckrodt Pharmaceuticals. Michael Morren, RPh, MBA, of Peloton Advantage, LLC, provided administrative and publishing support, funded by Mallinckrodt Pharmaceuticals.

\section{Disclosure}

Khurram Jamil and Krishna R Devarakonda are employees of Mallinckrodt Pharmaceuticals. Stephen Chris Pappas is an employee of Orphan Therapeutics, LLC. The authors report no other conflicts of interest in this work.

\section{References}

1. Forsling ML, Aziz LA, Miller M, Davies R, Donovan B. Conversion of triglycylvasopressin to lysine-vasopressin in man. $J$ Endocrinol. 1980;85(2):237-244.

2. Wisniewski K, Alagarsamy S, Taki H, et al. Synthesis and biological activity of terlipressin and its putative metabolites. In: Blondelle SE, editor. Understanding Biology Using Peptides: Proceedings of the Nineteenth American Peptide Symposium. San Diego, CA: Springer; 2006:489-490.

3. Sanyal AJ, Boyer T, Garcia-Tsao G, et al; Terlipressin Study Group. A randomized, prospective, double-blind, placebo-controlled trial of terlipressin for type 1 hepatorenal syndrome. Gastroenterology. 2008;134(5): $1360-1368$.

4. Boyer TD, Sanyal AJ, Wong F, et al; REVERSE Study Investigators. Terlipressin plus albumin is more effective than albumin alone in improving renal function in patients with cirrhosis and hepatorenal syndrome type 1. Gastroenterology. 2016;150(7):1579-1589.

5. Saner FH, Canbay A, Gerken G, Broelsch CE. Pharmacology, clinical efficacy and safety of terlipressin in esophageal varices bleeding, septic shock and hepatorenal syndrome. Expert Rev Gastroenterol Hepatol. 2007;1(2):207-217.

6. Ryckwaert F, Virsolvy A, Fort A, et al. Terlipressin, a provasopressin drug exhibits direct vasoconstrictor properties: consequences on heart perfusion and performance. Crit Care Med. 2009;37(3):876-881.

7. Kam PC, Williams S, Yoong FF. Vasopressin and terlipressin: pharmacology and its clinical relevance. Anaesthesia. 2004;59(10):993-1001.

8. Petersen MB. The effect of vasopressin and related compounds at V1a and V2 receptors in animal models relevant to human disease. Basic Clin Pharmacol Toxicol. 2006;99(2):96-103.

9. Tahara A, Saito M, Sugimoto T, et al. Pharmacological characterization of the human vasopressin receptor subtypes stably expressed in Chinese hamster ovary cells. Br J Pharmacol. 1998;125(7):1463-1470.

10. Cotte N, Balestre MN, Phalipou S, et al. Identification of residues responsible for the selective binding of peptide antagonists and agonists in the V2 vasopressin receptor. J Biol Chem. 1998;273(45):29462-29468.

11. Colson PH, Virsolvy A, Gaudard P, et al. Terlipressin, a vasoactive prodrug recommended in hepatorenal syndrome, is an agonist of human V1, V2 and V1B receptors: implications for its safety profile. Pharmacol Res. 2016;113(Pt A):257-264.

12. Bernadich C, Bandi JC, Melin P, Bosch J. Effects of F-180, a new selective vasoconstrictor peptide, compared with terlipressin and vasopressin on systemic and splanchnic hemodynamics in a rat model of portal hypertension. Hepatology. 1998;27(2):351-356. 
The Journal of Experimental Pharmacology is an international, peerreviewed, open access journal publishing original research, reports,

Visit http://www.dovepress.com/testimonials.php to read real quotes reviews and commentaries on all areas of laboratory and experimental pharmacology. The manuscript management system is completely online and includes a very quick and fair peer-review system.

Submit your manuscript here: https://www.dovepress.com/journal-of-experimental-pharmacology-journal 